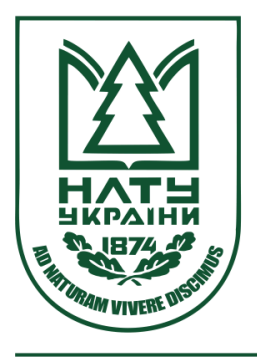

Науковий вісник НЛТУ України Scientific Bulletin of UNFU

https://nv.nltu.edu.ua

https://doi.org/10.36930/40310309

$@ \bowtie$ Correspondence author

Article received 12.04.2021 p.

Article accepted 29.04.2021 p.

T. I. Kovtun

UDC 595.786:591.53(477.42)

igkov@ukr.net

T. І. Ковтун

Поліський національний університет, м. Житомир, Україна

\title{
ОСОБЛИВОСТІ ФЕНОЛОГІЇ СОВКОПОДІБНИХ ЛУСКОКРИЛИХ (LEPIDOPTЕRА, NOCTUOIDEA) В УМОВАХ ПРИМІСЬКОÏ ЗОНИ МІСТА ЖИТОМИР
}

\begin{abstract}
Встановлено, що одним із аспектів екології Noctuoidea, які висвітлені недостатньо, є особливості сезонної динаміки (фенології) цієї групи комах. Упродовж періоду досліджень (2011-2020 рр.) зібрано 2770 екземплярів совкоподібних лускокрилих, що належать до 134 видів, 23 підродин і 3 родин. Літ імаго виявлених видів триває зазвичай зі середини березня до середини листопада. З'ясовано, що для совкоподібних досліджуваного району характерними є два типи діапаузи: літня та зимова. Літня діапауза притаманна для 7 видів $(5,2 \%)$ цього ноктуоїдного комплексу. Решта видів перебуває в зимовій діапаузі на різних стадіях життєвого циклу. Встановлено, що найбільшою в досліджуваній ентомофауні $є$ частка видів, що зимують на стадії гусені різного віку (56 видів; 41,8 \%). На стадії лялечки зимує 52 види (38,8 \%), яйця - 19 видів $(14,2 \%)$, імаго - 7 видів (5,2 \%). Виявлено види, що можуть зимувати на різних стадіях життєвого циклу. На стадії лялечки або гусені зимують 3 представники родини Noctuidae. Ще 3 представники цієї родини здатні зимувати на стадії або лялечки, або гусені, або імаго. З'ясовано, що Agrotis ipsilon (Hufnagel, 1766) в досліджуваному районі зимує тільки на стадії лялечки. Охарактеризовано особливості співвідношень між видами, що зимують на тій чи іншій стадії розвитку, в окремих родинах. Виявлено 3 види досліджуваної ентомофауни, що здатні до міграцій з південніших регіонів. Встановлено, що в умовах приміської зони Житомира 76 видів $(56,7 \%) є$ моновольтинними, для решти видів характерний полівольтинізм (причому в досліджуваному районі вони дають 2 генерації на рік). Відповідно до класифікації, запропонованої в роботі 3. Ф. Ключко, К. К. Голобородько та ін. (2011), здійснено розподіл фауни Noctuoidea досліджуваного району на фенологічні угруповання. Виявлено, що більшість видів совкоподібних належить до транссезонного угруповання (40 видів; 29,8 \%); літнє та літньоосіннє угруповання однакові за кількістю видів (по 33 види; 24,6 \%); до весняно-літнього угруповання входить 10 видів (7,5\%); весняне угруповання формують 8 видів (5,9\%); найменш чисельними є осіннє та осінньо-весняне угруповання (по 5 видів; $3,8 \%)$.
\end{abstract}

Ключові слова: терміни льоту імаго; стадії життєвого циклу; типи діапаузи; фенологічні угруповання; трансформовані біотопи; Житомирщина.

\section{Вступ}

Надродина совкоподібні (Lepidoptera, Noctuoidea) належить до тих таксонів лускокрилих, що вивчені найкраще. Вивчення видового різноманіття та ролі окремих видів в різних екосистемах має тривалу історію [1, $13,15]$, однак деякі аспекти екології совкоподібних висвітлені недостатньо. Одним 3 таких напрямів є вивчення сезонної динаміки (фенології) цієї групи метеликів.

Значну частину приміської зони Житомира займають антропогенно трансформовані біотопи. Для них характерним $є$ процес інтенсивної зміни фітоасоціацій внаслідок інтенсивного лісовідновлення, зниження пасовищного навантаження, припинення розорювання певної частини полів. Це призводить до достатньо швидкої зміни екологічних факторів, що формують умови існування популяцій совкоподібних таких екосистем. Вивчення фенологічних особливостей видів $€$ істотним для розуміння шляхів екологічних адаптацій видів до конкретних умов існування. Особливу актуальність фенологічні дослідження набувають з огляду на оцінювання впливу антропогенних змін на живі організми та природне середовище загалом.

Об'єкт дослідження - популяції совкоподібних лускокрилих (Lepidoptera, Noctuoidea) приміської зони Житомира.

Предмет дослідження - методи і засоби визначення фенологічної структури совкоподібних лускокрилих (Lepidoptera, Noctuoidea) в умовах приміської зони Житомира.

Мета роботи - вивчення особливостей фенології совкоподібних лускокрилих (Lepidoptera, Noctuoidea) в умовах приміської зони Житомира.

Для досягнення зазначеної мети визначено такі основні завдання дослідження: проаналізувати розподіл досліджуваних видів за типами діапаузи; встановити співвідношення зимуючих стадій виявлених видів; вивчити розподіл досліджуваної ентомофауни на фенологічні угруповання.

Наукова новизна отриманих результатів дослідження - вперше проаналізовано закономірності сезонного розвитку совкоподібних лускокрилих (Lepidoptera,

\section{Інформація про авторів:}

Ковтун Тетяна Ігорівна, канд. с.-г. наук, доцент, кафедра біології та захисту лісу. Email: igkov@ukr.net; https://orcid.org/0000-0003-1611-8030

Цитування за ДСтУ: Ковтун Т. І. Особливості фенології совкоподібних лускокрилих (Lepidoptera, Noctuoidea) в умовах приміської зони міста Житомир. Науковий вісник НЛтУ України. 2021, т. 31, № 3. С. 63-67.

Citation APA: Kovtun, T. I. (2021). Phenological composition of noctuid moths (Lepidoptera, Noctuoidea) in conditions of Zhytomyr suburban area. Scientific Bulletin of UNFU, 31(3), 63-67. https://doi.org/10.36930/40310309 
Noctuoidea) в умовах приміської зони Житомира.

Практична значущість результатів дослідження дані щодо фенологічних особливостей совкоподібних сприяють прогнозуванню стану популяцій цих комах, а також дають змогу планувати боротьбу з небезпечними для лісового та сільського господарств видами.

Аналіз останніх досліджень та публікацій. Фенологічну структуру ноктуоїдних лускокрилих досліджували в своїх роботах як вітчизняні, так і зарубіжні вчені, зокрема, Б. В. Добровольський, М. І. Фалькович, М. В. Несина, З. Ф. Ключко, К. К. Голобородько, О. Є. Пахомов, В. О. Барсов та інші [15].

Ключко 3. Ф., Голобородько К. К. та ін. (2011) аналізують закономірності сезонного розвитку нічних метеликів Дніпропетровської області. Посилаючись на роботу А. Х. Саулич та I. В. Соколової (2002), вони відзначають, що існує два типи сезонних схем життя комах: гомодинамний, що формується на підставі постійної активності особин певного виду; та гетеродинамний, який характеризується чергуванням періодів активності та спокою. Окрім цього, спираючись на концепцію М. І. Фальковича (1979), для умов Дніпропетровської області виділяють такі фенологічні угруповання совок: весняне (імаго яких розвивається з березня по кінець травня); весняно-літнє (літ імаго відбувається навесні і в червні); літне (імаго яких трапляються з червня по серпень); літньо-осіннє (імагінальні стадії спостерігаються восени); та транссезонне (імаго трапляються з березня по листопад, розвиток трьох або чотирьох поколінь). Також аналізують розподіл видів регіональної фауни Noctuoidea на полівольтинні та моновольтинні види [15].

Особливості фенології висвітлено в роботах, в яких досліджують фауну совкоподібних лускокрилих таких регіонів України: степової зони $[1,11]$; регіону Карпат [2]; Закарпатської області [9]; Донбасу [10].

Фенологічні особливості представників надродини Noctuoidea ентомофауни Білорусі вивчено у роботах Є. А. Держинського та А. В. Кулака $[4,5]$. У них подано аналіз річних циклів розвитку, характеристику фенологічних груп, динаміку льоту імаго досліджуваних груп комах тощо.

Деякі аспекти фенології регіональної фауни совкоподібних Росії висвітлено в роботах С. Ю. Гордєєва (Байкальський регіон) [8], В. В. Дубалотова (Хабаровський край) $[6,7]$. У них наведено списки видів Noctuoidea, що були виявлені в цих регіонах, з характеристикою деяких особливостей їх сезонного розвитку.

Вивчення сезонної динаміки комах ноктуоїдного комплексу на регіональному та локальному рівнях $є$ актуальним дотепер.

Матеріали та методи дослідження. Матеріали збирали в районі села Березівка, Житомирського району, Житомирської області впродовж польових сезонів 2011-2020 років. Район зборів (рис. 1), що займає площу близько 5 га, розташований на східній околиці Березівки, на відстані 15 км від Житомира. 3 північної і західної сторін ділянка обмежена меліоративними каналами; на південній межі розташована дубова полезахисна смуга; східною стороною ділянка межує з чагарниковою та низькорослою деревною рослинністю. У північно-східному секторі розташоване частково заболочене багно, заросле осокою (Cárex), вільхою сірою (Alnus incana L.) та малиною (Rubus idaeus L.) Найближчі житлові будівлі розміщені на відстані

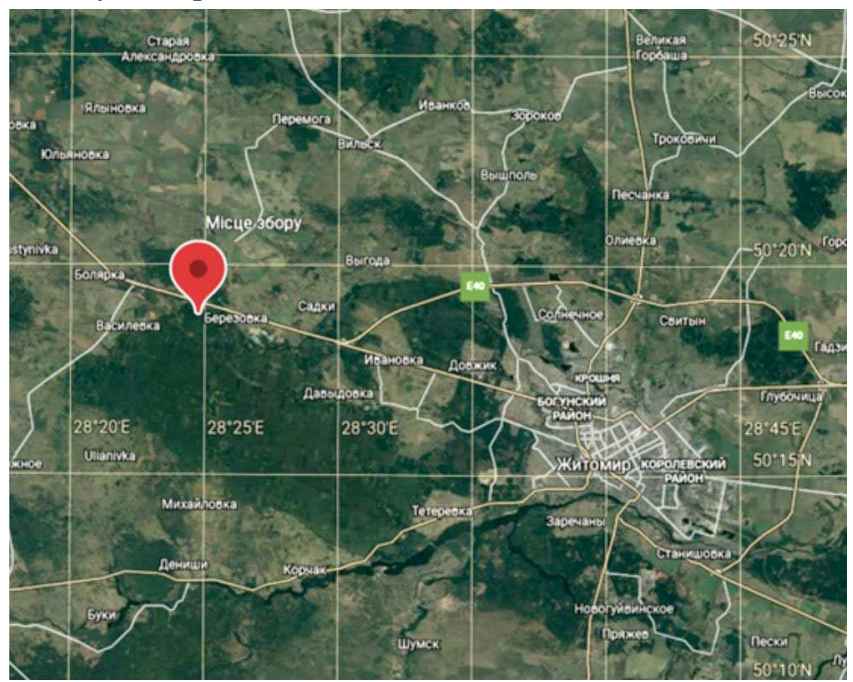

Рис. 1. Карта-схема району зборів Noctuoidea у приміській зоні Житомира

500 м від західного кордону ділянки. У південному напрямку на відстані 1,5 км проходить міжнародна траса Київ-Чоп, у цьому ж напрямку на відстані 3 км розташований Березівський гранітний кар'єр. Ділянка використовувалась упродовж тривалого часу (близько 40 років) як сільськогосподарські угіддя (під пасовище та посіви сільськогосподарських культур). У 1992 р. земля була виділена під індивідуальні городи. Активна діяльність городників тривала впродовж 10 років. 3 початку 2000-х років близько половини наділів не використовують під посадку сільськогосподарських культур, епізодично ведуть викошування трави і випасання худоби.

Для проведення фенологічних досліджень збори матеріалу відбувались на двох постійних пунктах обліку двічі на місяць упродовж польового сезону з використанням світлових пасток за загальноприйнятими ентомологічними методиками (Горностаев, 1984; Фасулати, 1971). Визначення матеріалу здійснювали за допомогою 13-томного видання Noctuidae Europaeae, 19902011.

Визначення термінів настання фенологічних періодів виконували відповідно до концепції М. І. Фальковича (1979) та В. О. Барсова (1977) [1, 15] на підставі зміни фенофаз рослин і динаміки температури повітря, які фіксували під час збирання матеріалу; використовували також дані метеорологічної станції Житомира [16]. Період льоту метеликів визначали на підставі власних 10-річних спостережень (2011-2020 рр.) на постійних пунктах обліку [14], а також користувались інформацією з фенології совкоподібних лускокрилих ентомофауни України [13], Польщі [3], Литви [12]. Розподіл совкоподібних досліджуваної ентомофауни на фенологічні угруповання здійснювали відповідно до класифікації, запропонованої в роботі З. Ф. Ключко, К. К. Голобородько та ін. (2011) [15]. Ця класифікація грунтується на тому, що формування постійних фенологічних груп совкоподібних здійснюється шляхом визначення кількості видів на стадії імаго, що в певний момент присутні в досліджуваній екосистемі. 


\section{Результати дослідження та їх обговорення}

Упродовж 2011-2020 pp. зібрано 2770 екземплярів совкоподібних лускокрилих, які відповідно до міжнародної систематики, належать до 134 видів, 23 підродин i 3 родин. Літ імаго виявлених видів спостерігається зазвичай зі середини березня до середини листопада.

Основними параметрами, що визначають особливості перебігу життєвих стадій нічними метеликами, $є$ загальні кліматичні особливості місцевості, їх варіації за роками, мезокліматичні характеристики різних біотопів тощо. Клімат району досліджень помірно континентальний; літо - тепле та вологе, зима - м'яка. Середньорічна температура становить $+6-+7^{\circ} \mathrm{C}$. Найхолоднішим місяцем $\epsilon$ січень (середня температура $-5,7^{\circ} \mathrm{C}$ ); найтеплішим - липень (середня температура $+18,9^{\circ} \mathrm{C}$ ). Переважають опади у вигляді дощу (в середньому випадає за рік 550-570 мм). Висота снігового покриву в середньому становить 20-30 см, але внаслідок частих відлиг сніговий покрив $є$ нестійким. Досліджуваний район перебуває під впливом атлантичних повітряних мас та зазнає впливу циклонів, яких нараховується в холодний період року (грудень-березень) до $30-35$, а в теплий (квітень-жовтень) приблизно 12-15. Це зумовлює значну мінливість клімату району досліджень [13].

Для совкоподібних приміської зони Житомира можна виділити два основних типи діапаузи - літню та зимову. Літня діапауза притаманна для 7 видів $(5,2 \%)$ цього ноктуоїдного комплексу. Зокрема, це Spaelotis ravida (Denis Schiffermüller, 1775), Agrotis exclamationis (L., 1758) та представники роду Noctua: N. interposita (Hübner, 1790), N. fimbriata (Schreber, 1759), N. pronuba (L., 1758), N. comes (Hübner, 1813).

Для решти видів характерна зимова діапауза, але діапазуючі стадії можуть бути різними (таблиця). Найбільш характерною для представників надродини $є$ зимівля гусені різного віку, що відзначена у 41,8 \% видів. На стадії лялечки зимують $38,8 \%$ видів, яйця $14,2 \%$ видів, імаго - 5,2 \% видів. Окрім цього, в досліджуваній ентомофауні виявлено види, що можуть зимувати на різних стадіях життевого циклу. На стадії лялечки або гусені зимують 3 представники родини Noctuidae: Ochropleura plecta (L., 1761) зимує на стадії лялечки, іноді гусені; у Noctua pronuba (L., 1758) зимуе гусінь IV віку та лялечки; у Anarta trifolii (Hufnagel, $1766)$ зимують лялечки або гусінь останнього віку. Ще 3 представники цієї родини здатні зимувати на стадії або лялечки, або гусені, або імаго. Agrotis ipsilon (Hufnagel,1766) у досліджуваному районі зимує лише на стадії лялечки. У Phlogophora meticulosa (L., 1758), окрім гусені, зимують також лялечки та імаго. Представники Autographa gamma (L., 1758) зимують на всіх стадіях, але найбільш морозостійкими є гусінь, пронімфи та лялечки. Також у представника родини Erebidae, Hypena proboscidalis (L., 1758), зимує гусінь, іноді лялечки або окремі особини імаго. Відзначено 2 види 3 родини Noctuidae, у представників яких іноді зимує гусінь, сформована всередині яйцевої оболонки: Tholera decimalis (Poda, 1761), Tholera cespitis (Denis \& Schiffermüller, 1775).

В окремих родинах співвідношення між видами, що зимують на тій чи іншій стадії розвитку, має свої особливості. У родині Noctuidae спостерігається загальна закономірність: переважають види, які зимують на стадії гусені (43,1 \%), на другому місці група видів з зимовою діапаузою на стадії лялечки $(39,8 \%)$, на третьому - види, що зимують на стадії яйця (13,0 \%). У родині Erebidae $33,4 \%$ виявлених видів зимують на стадії яйця: $\mathrm{Ca}$ tocala electa (Vieweg, 1790), Catocala fulminea (Scopoli, 1763) (= paranympha L., 1767) та Catocala elocata (Esper, 1787). Частка видів, що зимують на стадії гусені, імаго та лялечки, є однаковою та становить $22,2 \%$. На стадії гусені, окрім згаданого вище Hypena proboscidalis (L., 1758), зимує ще один вид - Polypogon tentacularia (L., 1758). На стадії імаго зимують Hypena rostralis (L., 1758) та Scoliopteryx libatrix (L., 1758), а на стадії лялечки - Euclidia mi (Clerck, 1759) та Colobochyla salicalis ([Denis et Schiffermüller], 1775). У досліджуваній ентомофауні виявлено 2 види, що належать до родини Nolidae, один з яких зимує на стадії гусені - Bena bicolorana (Fuessly, 1775), інший - на стадії лялечки - Pseudoips prasinana (L., 1758) (= fagana Fabricius, 1781).

Таблиця. Зимуючі стадії Noctuoidea приміської зони м. Житомир

\begin{tabular}{|c|c|c|c|c|c|c|c|c|c|}
\hline \multirow{3}{*}{$\begin{array}{l}\text { № } \\
\text { 3/ח }\end{array}$} & \multirow{3}{*}{$\begin{array}{c}\text { Зимуючі } \\
\text { стадії }\end{array}$} & \multirow{2}{*}{\multicolumn{2}{|c|}{$\begin{array}{l}\text { Надродина } \\
\text { Noctuoidea }\end{array}$}} & \multicolumn{6}{|c|}{ В тому числі, по родинах } \\
\hline & & & & \multicolumn{2}{|c|}{ Noctuidae } & \multicolumn{2}{|c|}{ Erebidae } & \multicolumn{2}{|c|}{ Nolidae } \\
\hline & & $\begin{array}{l}\text { К-ть } \\
\text { видів }\end{array}$ & $\%$ & $\begin{array}{c}\text { К-ть } \\
\text { видів }\end{array}$ & $\%$ & $\begin{array}{l}\text { К-ть } \\
\text { видів }\end{array}$ & $\%$ & $\begin{array}{c}\text { С-ть ви- } \\
\text { дів }\end{array}$ & \\
\hline 1 & & 56 & 41,8 & 53 & 43,1 & 2 & 22, & 1 & 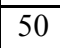 \\
\hline 2 & Лял & 52 & 8,8 & 49 & 39,8 & 2 & $\overline{22,2}$ & 1 & 50 \\
\hline 3 & Яйц & 19 & 14 & 16 & 13, & 3 & 33,4 & - & - \\
\hline 4 & & 7 & 5,2 & 5 & 4,1 & 2 & 22,2 & - & - \\
\hline & Всього & 134 & 100 & 123 & 100 & 9 & 100 & 2 & 10 \\
\hline
\end{tabular}

Три види досліджуваної ентомофауни здатні до міграцій $з$ південніших регіонів: Agrotis ipsilon (Hufnagel,1766), Phlogophora meticulosa (L., 1758), Autographa gamma (L., 1758). Більшість совкоподібних приміської зони Житомира щорічно розвивається в одному поколінні $(56,7 \%)$. Частка полівольтинних видів становить $43,3 \%$, причому в досліджуваному районі вони, зазвичай, дають 2 генерації. Щорічно у двох поколіннях розвиваються Autographa gamma (L., 1758) та Anarta trifolii (Hufnagel, 1766), які за даними 3.Ф. Ключко та ін. (2001) [13], у степовій зоні дають третє покоління.

У роботі З. Ф. Ключко, К. К. Голобородько та ін. (2011) [15] зазначено, що частка моновольтинних видів у фауні Noctuoidea в умовах Дніпропетровської області становить $62 \%$, решта видів належать до полівольтинної групи (зазвичай, бівольтинної). Відомо, що види, які дають одну генерацію на рік, за харчовою спеціалізацією належать переважно до дендробіонтів; натомість полівольтинізм характерний для хортобіонтів $[14,15]$.

Враховуючи дані про терміни льоту імаго за фенологічними періодами та особливості зимової діапаузи [13], совкоподібних лускокрилих приміської зони Житомира можна поділити на 7 фенологічних угруповань: весняне (імаго спостерігається з березня по травень); весняно-літне (види, літ яких спостерігається навесні та в червні); літнє (літ імаго відбувається з червня по серпень); літньо-осіннє (імагіальні стадії розвиваються зі середини або кінця липня та закінчують літ восени); осінне (імаго можна спостерігати тільки восени); осінньо-весняне (період льоту імаго триває з вересня по листопад і після зимівлі з березня по травень); транссе- 
зонне (імаго трапляються в природі з березня по листопад) (рис. 2).

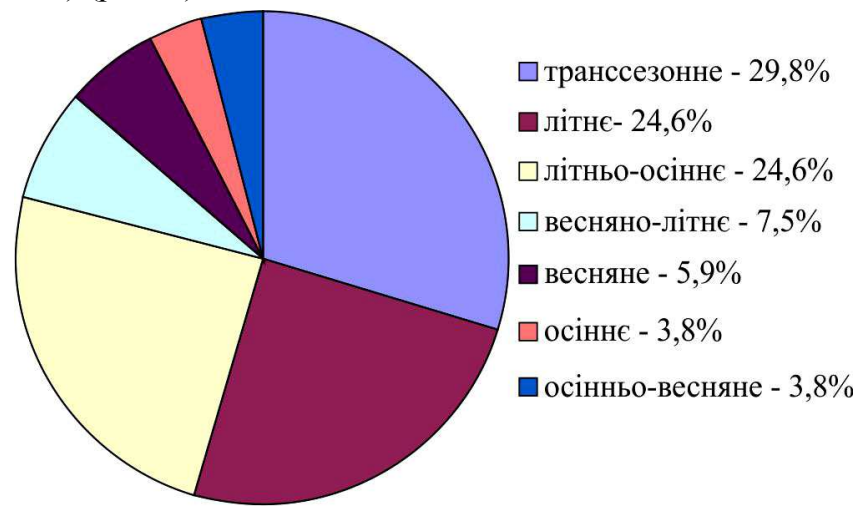

Рис. 2. Розподіл фауни Noctuoidea приміської зони Житомира на фенологічні угруповання

Найчисленнішою фенологічною групою совкоподібних досліджуваного району виявилась транссезонна, до якої віднесено 40 видів (29,8 \%). Зокрема, це представники роду Noctua: N. interposita (Hübner, 1790), N. pronuba (L., 1758); роду Mythimna: M. pallens (L., 1758), M. l-album (Denis \& Schiffermüller, 1775), M. albipuncta (Denis \& Schiffermüller, 1775) та Sideridis rivularis (Fabricius, 1775) (= cucubali [Denis et Schiffermüller], 1775). До цього угруповання належать полівольтинні види, що дають 2 генерації впродовж сезону. Виняток становить Noctua pronuba (L., 1758), яка розвивається в одному поколінні. Представники цієї групи зимують переважно на стадії лялечки (20 видів) або гусені (19 видів); 1 вид (Hypena rostralis (L., 1758)) зимує на стадії імаго. Деякі види є небезпечними шкідниками: Agrotis exclamationis (L., 1758), Agrotis segetum (Denis \& Schiffermüller, 1775), Agrotis ipsilon (Hufnagel,1766), Anarta trifoli (Hufnagel, 1766), Lacanobia suasa (Denis \& Schiffermüller, 1775), Xestia c-nigrum (L., 1758), Autographa gamma (L., 1758).

Літнє та літньо-осіннє угруповання виявились однаковими за кількістю видів. До них належить по 33 види (24,6 \%). До літнього угруповання належать представники підродини Noctuinae: Xestia triangulum (Hufnagel, 1766), Xestia ditrapezium (Denis \& Schiffermüller, 1775); підродини Hadeninae: Conisania luteago ([Denis et Schiffermüller], 1775) (= argillacea Hübner, [12, 16]), Hada plebeja (L.,1761), Lacanobia contigua (Denis \& Schiffermüller, 1775); підродини Xyleninae: Hoplodrina octogenaria (Goeze, 1781), Enargia paleacea (Esper, 1788), Oligia latruncula (Denis \& Schiffermüller, 1775); більшість видів підродини Acronictinae, зокрема, представники роду Acronicta: A. leporina (L., 1758), A. psi (L., 1758), A. megacephala ([Denis et Schiffermüller], 1775). Виявлено по одному виду з підродини Acontiinae (Aedia funesta (Esper, 1786)) та 3 підродини Eriopinae (Callopistria juventina (Stoll, 1782)), а також два виявлених види 3 родини Nolidae належать до літньої фенологічної групи. Для переважної більшості видів цієї групи характерна зимова діапауза на стадії гусені (18 видів) або лялечки (13 видів); 2 види зимують на стадії яйця. 18 видів цієї групи є моновольтинними, решта дають 2 покоління за рік.

Літньо-осіннє угруповання включає, зокрема, з родини Noctuidae представників роду Noctua (N. fimbriata (Schreber, 1759), N. comes (Hübner, 1813)); роду Tholera (T.cespitis (Denis \& Schiffermüller, 1775), T. decimalis
(Poda, 1761)); роду Xanthia (X. icteritia (Hufnagel, 1766), Xanthia togata (Esper, 1788)). Серед виявлених представників родини Erebidae до цього угруповання належать види роду Catocala (C. electa (Vieweg, 1790), C. fulminea (Scopoli, 1763) (= paranympha Linnaeus, 1767), C. elocata (Esper, 1787)). Переважна більшість видів цієї групи є моновольтинними (29 видів); 18 видів зимує на стадії гусені, причому для двох із них можлива зимівля гусені в яйцевій оболонці; 13 видів зимує на стадії яйця.

Четвертим за кількістю видів виявилось веснянолітнє угруповання, яке представлено 10 видами (7,5 \%). Це представники родини Noctuidae, зокрема, з підродини Hadeninae - Egira conspicillaris (L. 1758) та Polia nebulosa (Hufnagel, 1766); $з$ підродини Xyleninae - Apamea sordens (Hufnagel, 1766) та Dypterygia scabriuscula (L., 1758); $з$ підродини Acronictinae - Moma alpium (Osbeck, 1778) та Acronicta cuspis (Hübner, 1813) тощо. Це види переважно моновольтинні (8 видів), в зимовій діапаузі перебувають на стадії лялечки (6 видів) або гусені (4 види).

Невеликою є кількість видів весняного угруповання: 8 видів (5,9\%). Це, переважно, представники роду Orthosia: O. incerta (Hufnagel, 1766), O. cruda (Denis \& Schiffermüller, 1775), O. populeti (Fabricius, 1775), O. opima (Hübner, 1809), O. cerasi (Fabricius, 1775) (= stabilis [Denis et Schiffermüller], 1775), O. gothica (L., 1758). Усі вони належать до моновольтинних видів, які в період зимової діапаузи перебувають на стадії лялечки.

Найменшими за кількістю виявились осінне та осінньо-весняне угруповання. Кожне з них складається iз 5 видів $(3,8 \%)$. Усі види осінньої групи є моновольтинними, 4 види зимують на стадії яйця (Agrochola litura (L., 1758), Rhizedra lutosa (Hübner, 1803), Sedina buettneri (E. Hering, 1858), Allophyes oxyacanthae (L., 1758)), 1 вид - на стадії лялечки (Diloba caeruleocephala (L., 1758)).

Види, що належать до осінньо-весняного угруповання, $є$ представниками підродини Xyleninae. Це моновольтинні види, що зимують на стадії імаго. Для Соnistra vaccinii (L., 1761) та Eupsilia transversa (Hufnagel, 1766) характерною є літня діапауза гусені.

Виділення певних узагальнень фенологічних спостережень $є$ досить непростим завданням. Порівняння фенологічної структури ноктуоїдного комплексу досліджуваного району та угруповань совкоподібних Дніпропетровської області [15] дає змогу стверджувати про доволі високу схожість такої структури. Найчисленнішим у фауні совкоподібних Дніпропетровської області також $є$ транссезонне угруповання (37\%); друге місце займає літнє угруповання (28 \%); третьою є літньо-осіння група $(26 \%)$.

\section{Висновки}

Унаслідок здійснених досліджень встановлено, що для совкоподібних приміської зони Житомира характерними є два типи діапаузи - літня та зимова. Причому переважає зимова діапауза. У досліджуваному ентомокомплексі виявлено види, що зимують на стадії яйця, гусені, лялечки та імаго. Найбільша кількість видів зимує на стадії гусені. Більшість видів досліджуваного ноктуоїдного комплексу є моновольтинними. Полівольтинні види в умовах приміської зони Житомира дають два покоління. 
Совок досліджуваного району поділено на 7 фенологічних груп: весняну, весняно-літню, літню, літньоосінню, осінню, осінньо-весняну та транссезонну. За кількістю видів переважає транссезонне угруповання, другим та третім виявились літне та літньо-осіннє угруповання, до яких належить однакова кількість видів.

Загалом виявлені особливості фенології свідчать про достатньо високий рівень адаптації Noctuoidea приміської зони Житомира до постійної зміни гігротермічних умов, що є надзвичайно важливим в умовах антропогенно трансформованих біогеоценозів.

\section{References}

1. Barsov, V. A. (1977). K fenologii kompleksov vesennikh cheshuekrylykh $\mathrm{v}$ lesnykh biogeotcenozakh IugoVostochnoi Ukrainy. Voprosy stepnogo lesovedeniia i okhrany prirody, 7, 102-108. Dnepropetrovsk: Izdvo DGU. [In Russian]

2. Bidichak, R. M., \& Sirenko, A. G. (2007). Rannolitnia fauna sovok (Noctuidae, Lepidoptera) dolini r. Tisa bilia Marmaroskogo masivu Karpatskogo biosfernogo zapovidnika. Visnik Prikarpatskogo natcionalnogo universitetu. Series: Biologiia. Ivano-Frankivsk, 7-8, 178-182. [In Russian].

3. Buszko, J., \& Maslowski, J. (2012). Motyle nocne Polski. Macrolepidoptera. Część I. Nowy Sacz: Koliber, 300 p.

4. Derzhinskii, E. A. (2015). Predvaritelnye rezultaty izucheniia osennikh vidov cheshuekrylykh nadsemeistva Noctuoidea v Belarusi. Sovremennye problemy entomologii Vostochnoi Evropy: materialy I mezhdunar. nauch.-prakt. konf., (pp. 99-102). Minsk: Ekoperspektiva. [In Russian].

5. Derzhinsky, Y. A., Kulak, A. V. (2015). Contributions to the knowledge of the Noctuoidea (Lepidoptera) of the Republic of Belarus. Entmological Review, 95, 1225-1236. St.-Petersburg. https:// doi.org /10.1134/S0013873815090109

6. Dubatolov, V. V. (2019). K faune cheshuekrylykh (Lepidoptera) khvoinykh lesov Botchinskogo zapovednika: dopolneniia po Macroheretocera bez Geometridae 2017-2018 godov. Amurskii zoologicheskii zhurnal, 11(2), 144-158. S.-Peterburg: Nauka. https://doi.org/10.33910/2686-9519-2019-11-2-144-158
7. Dubatolov, V. V. (2020). Macroheterocera (Insecta, Lepidoptera) Natcionalnogo parka "Aniuiskii" (Khabarovskii krai). Amurskii zoologicheskii zhurnal, 12(4), 490-512. S.-Peterburg: Nauka. https://doi.org/10.33910/2686-9519-2020-12-4-490-512

8. Gordeev, S. Iu., Gordeeva, T. V., \& Rudykh, S. G. (2019). Fauna Erebidae, Nolidae, Noctuidae (Lepidoptera, Noctuoidea) severnoi chasti Selenginskogo Srednegoria. Priroda Vnutrennei Azii, 2(11), 7-29. Ulan-Ude. https://doi.org /10.18101/2542-0623-2019-2-7-29

9. Heriak, Yu. M. (2010). Luskokryli nadrodyny Noctuoidea (Insecta, Lepidoptera) Zakarpatskoi oblasti. Naukovyi visnyk Uzhhorodskoho universytetu. Series: Biolohiia, 29, 126-139. [In Ukrainian].

10. Heriak, Yu. M., Demianenko, S. O., Konovalov, S. V., \& Martynov, V. V. (2015). Do vyvchennia noktuoidnykh luskokrylykh (Lepidoptera: Noctuoidea) Donbasu. Naukovi osnovy zberezhennia biotychnoi riznomanitnosti, 6(13), No. 1, 205-234. [In Ukrainian].

11. Holoborodko, K. K., Makhina, V. O., Buchnieva, K. S., \& Pakhomov, O. Ye. (2016). Hlobalno ridkisni vydy luskokrylykh (Lepidoptera), shcho okhoroniaiutsia v pryrodnomu zapovidnyku "Dniprovsko-Orilskyi". Ekolohiia ta noosferolohiia. Dnipropetrovsk, 27(3-4), 47-54. https://doi.org/10.15421/031613

12. Ivinskis, P. (2004). Lepidoptera of Lithuania. Annotated catalogue. Vilnius: Vilniaus universiteto Ecologijos instituto leidykla, $380 \mathrm{p}$.

13. Kliuchko, Z. F., Pliushh, I. G., \& Sheshurak, P. N. (2001). Annotirovannyi katalog sovok (Lepidoptera, Noctuidae) fauny Ukrainy. Kiev: Institut zoologii NAN Ukrainy, 884 p. [In Russian].

14. Kovtun, T. I. (2018). Ohliad trofichnykh zv, yazkiv huseni sovkopodibnykh (Lepidoptera: Noctuoidea) v umovakh napivpryrodnykh ekosystem prymiskoi zony mista Zhytomyr. Lviv: Scientific Bulletin of UNFU, 28(3), 26-29. https://doi.org/10.15421/40280305

15. Pakhomov, O. Ye., (Ed.), Kliuchko, Z. F., et. al. (2011). Biolohichne riznomanittia Ukrainy. Dnipropetrovska oblast. Vyshchi riznovusi luskokryli. Part 2. Sovky (Lepidoptera: Noctuidae), Dnipropetrovsk: Vyd-vo Dnipropetr. nats. un-tu, 546 p. [In Ukrainian].

16. Pohoda v Zhytomyri. (data zvernennia: 24.03.2021). Retrieved from: https://www.rp5.ua

T. I. Kovtun

Polissia National University, Zhytomyr, Ukraine

\section{PHENOLOGICAL COMPOSITION OF NOCTUID MOTHS (LEPIDOPTERA, NOCTUOIDEA) IN CONDITIONS OF ZHYTOMYR SUBURBAN AREA}

The aim of the study is to analyze the phenological composition of noctuid moths (Lepidoptera: Noctuoidea) in conditions of Zhytomyr suburban area. Research has been conducted during the field seasons of 2011-2020 on two eternal plots which were equipped with light traps according to generally accepted entomological methods. Identification of Noctuoidea was carried out with the help of Noctuidae Europaeae publication, 1990-2011. During the research period, 2770 specimens of Noctuoidea belonging to 134 species, 23 subfamilies and 3 families, were collected. The flight of identified species imago is usually observed from midMarch to mid-November. We have revealed that summer diapause inherent for 7 species $(5.2 \%)$ of this Noctuoidea complex. The remaining species are on winter diapause at the different stages of the life cycle. The share of species, that overwinter at the stage of larvae of different ages ( 56 species; $41.8 \%)$ is found to be the largest. On the stage of pupa, 52 species $(38.8 \%)$, egg - $19 \mathrm{species}$ $(14.2 \%)$, imago -7 species $(5.2 \%)$ overwinter. Some species that can overwinter at the different stages of the life cycle were also found. Agrotis ipsilon (Hufnagel, 1766) overwinter only at the stage of pupa in the study area. The peculiarities of the relations between the species that overwinter at different stages of development in separate families are characterized. Three species of the studied entomofauna are identified to be capable of migrations from the southern regions. Moreover, 76 species $(56.7 \%)$ are monovoltinis in conditions of Zhytomyr suburban area, polyvoltinis is characteristic of other species (moreover, they give 2 generations per year in the study area). Noctuoidea of study area were divided into 7 phenological groups. Most of Noctuoidea species belong to the transseasonal group ( 40 species; $29.8 \%$ ); summer and summer-autumn groups are the same in the number of species (33 species each; $24.6 \%)$; the spring-summer group includes 10 species $(7.5 \%)$; the spring group consists of 8 species $(5.9 \%)$; the least numerous are the autumn and autumn-spring groups ( 5 species each; $3.8 \%$ ). The identified features of phenology indicate a fairly high level of adaptation of Noctuoidea of Zhytomyr suburban area to the constant change of hygrothermal conditions.

Keywords: terms of flight of imago; life cycle stages; types of diapause; phenological groups; transformed biotopes; Zhytomyr region. 